\title{
Particle capture by marine bacteria
}

\author{
Yuna Seo*, Eiko Ikemoto, Akihiro Yoshida, Kazuhiro Kogure \\ Ocean Research Institute, The University of Tokyo, 1-15-1, Minamidai, Nakano-ku, Tokyo 164-8639, Japan
}

\begin{abstract}
In aquatic environments large numbers of submicron particles are generally present, and their turnover and fate are of considerable ecological importance in geochemical cycles. Efficient degradation of submicron particles can be attained if the particles are retained on the surfaces of bacterial cells rather than remaining suspended in the aqueous phase. We hypothesized that some bacterial groups possess particle-capture (PC) ability. To verify this hypothesis, we took 2 approaches. First, paramagnetic particles were added to natural seawater samples to separate out bacterial groups with PC capabilities. Method development was carried out in combination with community structure analysis of the separated bacteria by denaturing gradient gel electrophoresis (DGGE) and multidimensional scaling (MDS). Bacterial groups recovered by this new approach were different from either the representative ones in the original seawater sample or large particle associated bacterial groups. Second, atomic force microscopy was used to directly observe the submicron particles within natural bacterial populations. The number of cells retaining submicron particles was high in the inner part of Tokyo Bay and at depths of 500 to $2000 \mathrm{~m}$ in the open ocean. We concluded that there are bacterial groups in natural seawater that possess PC ability and we successfully collected these cells using the new paramagnetic particle method presented here.
\end{abstract}

KEY WORDS: Submicron particles - Particle-capturing ability · DGGE-MDS · Atomic force microscopy $\cdot$ AFM

Resale or republication not permitted without written consent of the publisher

\section{INTRODUCTION}

Natural seawater contains particles ranging in size from the submicron to centimeter scales, or even larger (Koike et al. 1990, Jackson \& Burd 2002, O'Dowd et al. 2004). The size distribution of these particles is continuous and the number of particles increases with decreasing particle size (Yamasaki et al. 1998). The numbers of submicron particles (SMPs) (Koike et al. 1990) or colloids exceed those of bacterial cells by 1 or 2 orders of magnitude (Longhurst et al. 1992, Wells \& Goldberg 1994). As the vertical distribution of these SMPs tends to parallel that of living organisms (Koike et al. 1990, Sieracki \& Viles 1992), they are generally regarded to be of biological origin (Yamasaki et al. 1998). Therefore, an understanding of the mechanisms of production and degradation of SMPs is important in clarifying the turnover of organic materials in the ocean; in turn, it is vital to gain knowledge of how bacterial cells interact with these particles and degrade them. Although heterotrophic bacteria are known to be the most important sinks of colloidal organic matter in the ocean (Amon \& Benner 1994), there have so far been few studies (Yamasaki et al. 1998) of the process of colloidal matter storage.

We hypothesize that bacteria contact and retain SMPs on their cell surfaces before hydrolysis, and that this is a key step in the efficient utilization of these particles. We call this process 'particle-capture' (PC). To test this hypothesis, we first used paramagnetic particles to confirm the presence of PC. Second, we used paramagnetic particles of various sizes and compositions to determine whether PC was influenced by the size and/or composition of the particles. Finally, we used atomic force microscopy (AFM) to observe SMPs on naturally occurring bacterial cells.

Paramagnetic particles have been used to detect and collect particular biomolecules or bacterial pathogens (Pyle et al. 1999, Brzeska et al. 2004). Molecules or cells adsorbed onto the particles are concentrated and recovered by suitable magnetic equipment. We assumed that the same procedure would be applicable for con- 
firming the presence of PC ability among natural bacteria and that certain bacterial groups would possess high PC ability. To examine the reliability of this new approach we used denaturing gradient gel electrophoresis (DGGE) and multidimensional scaling analysis (MDS) to compare the community structures of bacteria that retained paramagnetic particles with those of the bacteria in natural seawater. In addition, we used model particles of various sizes and compositions to separate out the bacteria that associated with them, and then applied DGGE-MDS analysis to these bacteria.

To directly observe the presence of SMPs on the surfaces of natural bacterial cells, it was necessary to use an optical device with high resolution and minimal artifacts. For simplicity and high resolution, we applied AFM to the natural bacterial cells that were concentrated on the filters (Nishino et al. 2004).

\section{MATERIALS AND METHODS}

Seawater sampling. For method development and the application of various model particles, seawater samples were collected from Tokyo Bay at Shinagawa Port on 21 February 2005 and 3 October 2006, and Yokohama Port on 9 January and 9 October 2006. Samples were collected from the surface layer with a sterile bottle and brought back to the Ocean Research Institute, The University of Tokyo. Sample treatments (see next section) were initiated within $2 \mathrm{~h}$ of sampling.

For observations by AFM, seawater samples were obtained from Tokyo Bay, Sagami Bay and offshore environments during the KT-05-16 cruise of RV 'Tansei Maru' (Ocean Research Institute, The University of Tokyo, and Japan Agency for Marine-Earth Science and Technology [JAMSTEC]) from 13 to 21 July 2005 (Fig. 1). Stns S1, S2 and S3 were located in the southern, middle and northern regions, respectively, of the Kuroshio Current. Water samples were collected vertically through the water column with a CTD-Carousel sampler. Samples were fixed with $1 \%$ formalin $(\mathrm{v} / \mathrm{v})$ and stored at $4{ }^{\circ} \mathrm{C}$ until analysis, which was initiated within 3 mo after sampling.

Preparation of 'total' and 'free-living' fractions. To determine whether bacterial PC differed from the bacterial attachment process, both natural seawater (the 'total' bacterial fraction, sT) and filtered seawater (the 'free-living' bacterial fraction, $\mathrm{sF}$, obtained by filtering through a $3 \mu \mathrm{m}$ Whatman Nuclepore filter) were treated in parallel. The attached bacterial fraction (Att) was defined as the fraction retained on the Nuclepore filter. The filter was frozen at $-20^{\circ} \mathrm{C}$ in $500 \mu$ of SET buffer (Sucrose EDTA Tris-HCl: 20\% sucrose [w/v], 50 mM EDTA, 50 mmol ${ }^{-1}$ Tris-HCl, pH 7.6) until DNA extraction.

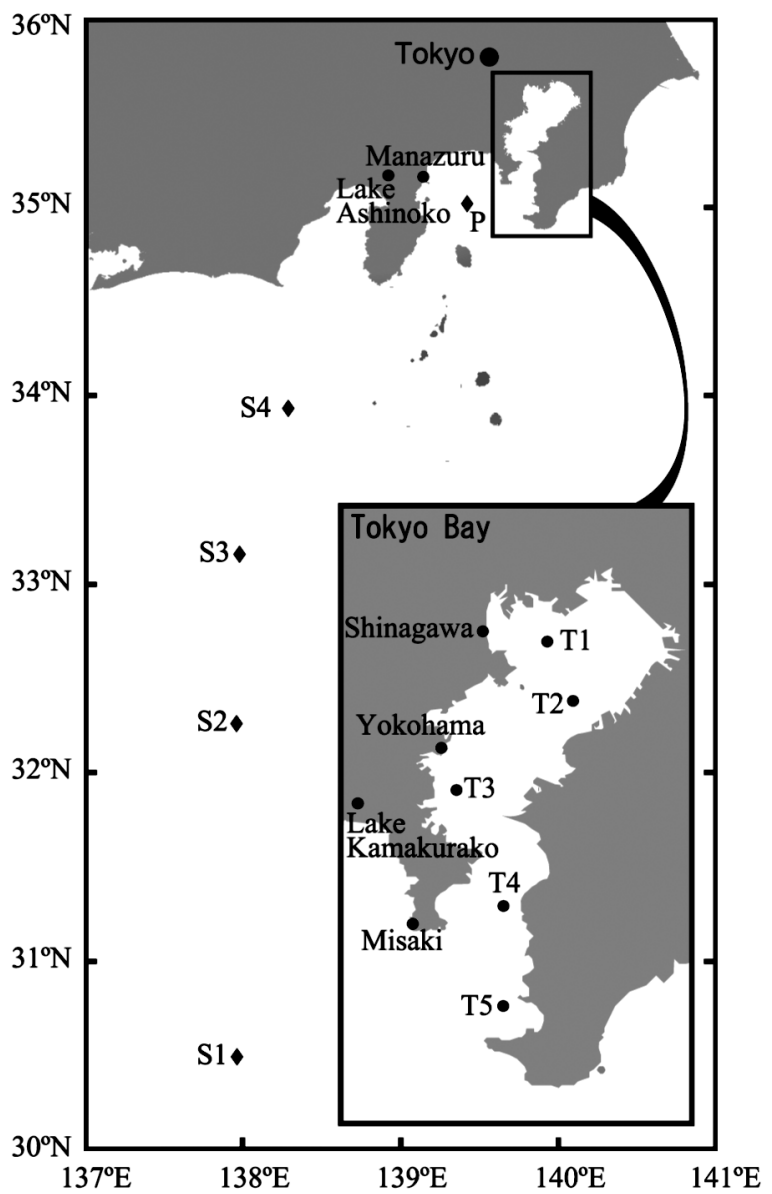

Fig. 1. Sampling locations in Tokyo Bay (Shinagawa Port, Yokohama Port, T1 to T5), Sagami Bay (P), and open ocean (S1 to $\mathrm{S} 4)$

Three replicate $1 \mathrm{ml}$ subsamples from the total and the free-living bacterial fractions were centrifuged at $21000 \times g$ for $10 \mathrm{~min}$. The cell pellets were then frozen until DNA extraction. To determine whether the species diversity in the $1 \mathrm{ml}$ subsamples represented that in the original seawater samples, $400 \mathrm{ml}$ of the total (T) and free-living (F) bacterial fractions were also collected by passing each fraction through a $0.22 \mu \mathrm{m}$ Sterivex GS filter (Millipore). The Sterivex filters were rinsed with SET buffer and frozen until DNA extraction.

Magnetic separation method. The magnetic separation method was first applied to biodegradable paramagnetic particles (nominal diameter $130 \mathrm{~nm}$, Micromod) polymerized with dextran in aqueous suspension. They were suspended in phosphate buffered saline (PBS, pH 7.5) and stored at $4^{\circ} \mathrm{C}$ until use. The sample seawater collected at Shinagawa Port on 21 February 2005 was used. Three replicate $1 \mathrm{ml}$ subsamples of the total and free-living bacterial fractions were transferred to $1.5 \mathrm{ml}$ microcentrifuge tubes, and 
separation was initiated immediately by addition of $20 \mu \mathrm{l}$ of the particle suspension (ca. $7.3 \times 10^{12}$ particles $\mathrm{ml}^{-1}$ ). The mixtures were incubated at room temperature for $1 \mathrm{~h}$ on a sample mixer (Dynal) at $10 \mathrm{rpm}$. After incubation, the paramagnetic particles were collected with a 12 tube magnet (Qiagen) for $3 \mathrm{~min}$ and the supernatants were removed carefully (Pyle et al. 1999). The particles were rinsed twice with PBS and frozen until DNA extraction. The subsamples from the free-living bacterial fraction were designated as 130nmDF (replicates a, b, and c) and from the total bacterial fraction as 130nmDT (replicates a, b, and c). Magnetically separated samples were designated on the basis of particle size and composition as follows: $130 \mathrm{nmDF}$ $(130 \mathrm{~nm}$, dextran); 150nmSF (150 nm, silica); 250nmDF (250 nm, dextran); 300nmSF (300 nm, silica); 500nmDF $(500 \mathrm{~nm}$, dextran); 500nmSF $(500 \mathrm{~nm}$, silica); $6 \mu \mathrm{mSF}(6 \mu \mathrm{m}$, silica); $6 \mu \mathrm{mPF}$ (6 $\mu \mathrm{m}$, polylactic acid) (Table 1).

The incubation time of $1 \mathrm{~h}$ with the paramagnetic particles was chosen on the basis of microscopic observations that showed the number of bacterial cells associated with the model particles (130nmDF) increased with time for the first 20 to $30 \mathrm{~min}$ and then remained relatively constant for $3 \mathrm{~h}$. This was the case in both natural bacterial populations and cultured bacterial species (Pseudomonas aeruginosa PAO1 and Vibrio parahaemolyticus, data not shown). To test whether the apparent bacterial community structure changed with incubation time, filtered seawater samples $(3 \mu \mathrm{m}$ filtrate) obtained from Yokohama Port in Tokyo Bay on 9 January 2006 were mixed with paramagnetic particles $(130 \mathrm{nmDF})$ and incubated for up to $48 \mathrm{~h}$ while being mixed on the sample mixer. Particles were collected as described previously after incubation for 1,2 , $4,8,24$ or $48 \mathrm{~h}$, and then frozen. Simultaneously, $1 \mathrm{ml}$ of the free-living bacterial fraction incubated at room temperature was sampled for use as a control, centrifuged at $21000 \times g$ for $10 \mathrm{~min}$, and frozen.

Effect of particle size and composition. In October 2006, 11 of seawater was collected from Yokohama Port and 11 from Shinagawa Port. Replicate $1 \mathrm{ml}$ subsamples of the free-living bacterial fraction were separated as described previously. Particles polymerized with dextran $(130 \mathrm{~nm}, 250 \mathrm{~nm}, 500 \mathrm{~nm})$, silica $(150 \mathrm{~nm}$, $300 \mathrm{~nm}, 500 \mathrm{~nm}, 6 \mu \mathrm{m})$, or polylactic acid $(6 \mu \mathrm{m})$ (Micromod) were prepared and $20 \mu \mathrm{l}$ of each suspen- sion was added to each $1 \mathrm{ml}$ subsample (Table 1). Each type of particle was added to the seawater samples in such a way that the total particle surface area per unit volume of seawater was kept constant.

DNA extraction and PCR amplification. DNA from magnetically separated and centrifuged samples was obtained with a DNeasy Tissue kit (Qiagen) in accordance with the manufacturer's instructions. DNA from total, free-living and attached samples was extracted as described by Yoshida et al. (2006).

PCR amplification was performed with a GeneAmp 9700 PCR System (Applied Biosystems) using the primers GC341f (Muyzer et al. 1993) and 907r (Muyzer et al. 1998). Initial denaturation was at $94^{\circ} \mathrm{C}$ for $5 \mathrm{~min}$, followed by adding $0.5 \mu \mathrm{l}$ of Z-tag DNA polymerase (TaKaRa) at $80^{\circ} \mathrm{C}$ (Chou et al. 1992) to reduce unexpected priming, annealing for $10 \mathrm{~s}$ at $65^{\circ} \mathrm{C}$, and extension for $20 \mathrm{~s}$ at $72^{\circ} \mathrm{C}$. Thermal cycling programs were as follows: denaturation for $2 \mathrm{~s}$ at $98^{\circ} \mathrm{C}_{i}$ annealing for $10 \mathrm{~s}$ at an initial $65^{\circ} \mathrm{C}$, then decreasing by $1^{\circ} \mathrm{C}$ every 2 cycles to a final $55^{\circ} \mathrm{C}$ (Don et al. 1991) to reduce unexpected priming; and extension for $20 \mathrm{~s}$ at $72^{\circ} \mathrm{C}$. The total number of cycles was adjusted between 27 and 35 depending on the DNA concentrations of the templates to avoid PCR artifacts (Kanagawa 2003). 
Denaturing gradient gel electrophoresis. The concentration of PCR products was estimated by comparison with a molecular mass standard (EzLoad DNA Mass Ruler). Then 200 ng of PCR product was analyzed by DGGE as described previously (Yoshida et al. 2006). Bands in the DGGE profiles were detected with ImageGauge 4.0 software (Fuji Photo Film); a band was identified as being present if the ratio of its peak height to the total peak height in the profile was $>1 \%$. The DGGE banding pattern in each lane was converted into a binary matrix indicating the presence (1) or absence (0) of each band in all the lanes. The similarities of the samples were visualized from an MDS map based on a distance matrix calculated from the binary matrices (Van Hannen et al. 1999). The MDS analysis was conducted with the software package $\mathrm{R}$ (www.r-project.org/).

DNA sequencing. Bands of interest were excised from the gel. Gel slices were re-amplified as described above and resolved by DGGE alongside the original sample. PCR products for sequencing were purified using a QIAquick Gel Extraction kit (Qiagen) in accordance with the manufacturer's protocol. Sequencing was performed with a BigDye Cycle Sequencing Ready Reaction kit (Applied Biosystems) and an Applied Biosystems 3100 genetic analyzer. Sequences between primer regions were aligned to known sequences using BLAST (www.ncbi.nlm.nih.gov/ BLAST/; Altschul et al. 1990), and nearest-neighbor alignments were performed with CLUSTAL W (Thompson et al. 1994). The accession numbers were EF123234 to EF123252.

Bacterial abundance. Subsamples of the total, free living and magnetically separated bacterial fractions were fixed with filtered $(0.2 \mu \mathrm{m}$ pore size) formaldehyde $\left(1 \% \mathrm{v} / \mathrm{v}\right.$, final concentration) and stored at $4{ }^{\circ} \mathrm{C}$ until enumeration. Subsamples were stained with 4',6diamidino-2-phenylindole (DAPI, $1 \mu \mathrm{g} \mathrm{ml}^{-1}$ ) and filtered onto black, $0.2 \mu \mathrm{m}$ pore size membrane filters (Nuclepore) (Porter \& Feig 1980). Bacterial cells were counted in 20 randomly selected fields at a magnification of 1000x under an epifluorescence microscope (model BX51, Olympus). At least 300 cells were counted on each sample filter.

AFM analysis. Bacterial cells collected from Tokyo Bay, Sagami Bay and the offshore stations during the KT-05-16 cruise of RV 'Tansei Maru' (Fig. 1) were observed by AFM (model SPM-9500 J2, Shimadzu) according to the method of Nishino et al. (2004). In brief, fixed seawater samples were filtered through Isopore filters $(0.2 \mu \mathrm{m}$ pore size, Millipore), air-dried and then observed directly using AFM in the dynamic mode. The AFM instrument was equipped with a microfabricated and oxide-sharpened $\mathrm{Si}_{3} \mathrm{~N}_{4}$ cantilever (OMCL-AC160TS-C1, Olympus) with a pyramidal tip and a force of $42 \mathrm{~N} \mathrm{~m}^{-1}$. Bacterial cells were differentiated from non-living particles on the basis of their size, shape and cross-section (Nishino et al. 2004). Cells with particulate materials around them were counted, and the relative number of particle-possessing cells among the total number of bacterial cells was determined. At least 100 cells were observed in each sample.

\section{RESULTS}

\section{Effectiveness of the magnetic separation method}

The methodology for collecting bacterial cells with PC ability was first examined with seawater collected from Shinagawa Port in Tokyo Bay on 21 February 2005. Bacterial abundances in magnetically separated samples $(130 \mathrm{nmDT}, 130 \mathrm{nmDF})$ averaged $1.4 \times 10^{5}$ and $1.5 \times 10^{5}$ cells ml ${ }^{-1}$, respectively, which corresponded to $7.6 \%$ of total bacteria $\left(2.7 \times 10^{6}\right.$ cells ml $\left.{ }^{-1}\right)$ and $15 \%$ of free-living bacteria $\left(1.7 \times 10^{6}\right.$ cells ml $\left.^{-1}\right)$. Standard deviations were $5.3 \times 10^{4}$ cells ml ${ }^{-1}(130 \mathrm{nmDF})$ and $3.5 \times 10^{4}$ cells ml ${ }^{-1}(130 \mathrm{nmDT})$. The number of paramagnetic particles added to the samples was about 5 orders of magnitude larger than that of bacterial cells. We assumed that the $1 \mathrm{~h}$ incubation period with shaking would ensure frequent collision of the particles with the bacterial cells, so that the collision rate would not be the rate-determining step.

The banding patterns on the DGGE profiles of $130 \mathrm{nmDF}$ and $130 \mathrm{nmDT}$ were similar among each replicate $(a, b, c)$ (Fig. 2A). The banding patterns of $130 \mathrm{nmDF}$ and $130 \mathrm{nmDT}$ were considerably different from those of the natural seawater samples ( $\mathrm{sF}$ and $\mathrm{F}$, sT and T) and the particle attachment sample (Att), respectively. In Fig. 2A the arrows indicate bands that appeared relatively prominent in $\mathrm{sF}, \mathrm{sT}, \mathrm{F}, \mathrm{T}$ or Att, but were absent from $130 \mathrm{nmDF}$ or $130 \mathrm{nmDT}$, or bands that appeared only in $130 \mathrm{nmDF}$ or $130 \mathrm{nmDT}$. When MDS analysis was applied (Fig. 2B), the communities of $130 \mathrm{nmDF}$ and $130 \mathrm{nmDT}$ were plotted away from other samples on the map, indicating that the magnetically separated bacterial communities were different from those of the natural seawater fraction and the particle attachment fraction. The banding patterns from different sample scales of natural seawater samples $(1 \mathrm{ml}$ for $\mathrm{sF}$ and $\mathrm{sT}$, and $400 \mathrm{ml}$ for $\mathrm{F}$ and $\mathrm{T}$ ) agreed well (Fig. 2A), a finding that was also indicated on the MDS map (Fig. 2B). Except for sTa, each set of 3 replicates was plotted closely together; thus, the reproducibility was generally high under our experimental conditions. Replicate sTa, however, showed that even if the seawater sample were mixed well, a $1 \mathrm{ml}$ subsample might occasionally have some bias. 
A

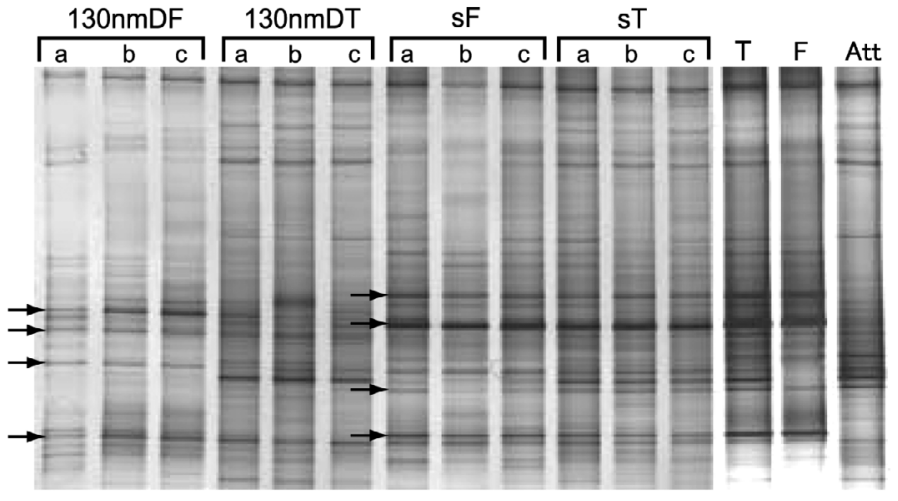

B

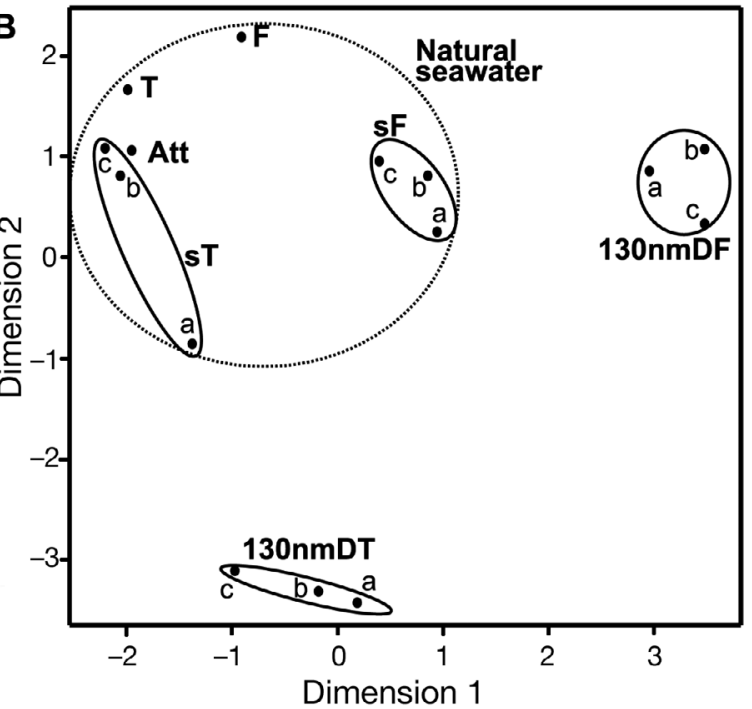

Fig. 2. (A) DGGE and (B) MDS images used for method evaluation with $130 \mathrm{~nm}$ diameter dextran particles. $\mathrm{sF}$ and F: bacteria collected from 1 and $400 \mathrm{ml}$ of the free-living fraction, respectively; sT and T: bacteria collected from 1 and $400 \mathrm{ml}$ of the total fraction, respectively; Att: particle-attached bacteria; 130nmDF and 130nmDT: bacteria magnetically separated from the free-living and total fractions, respectively; $\mathrm{a}, \mathrm{b}$, and c: replicate subsamples. Arrows in (A) indicate bands that appear relatively bright in $\mathrm{sF}$ or $\mathrm{sT}$, but are absent from $130 \mathrm{nmDF}$ or $130 \mathrm{nmDT}$, or that appear only in 130nmDF or 130nmDT

Subsamples of $3 \mu \mathrm{m}$ filtrate collected from Yokohama Port in Tokyo Bay on 9 January 2006 were incubated with particles (130nmDF, 130nmDT) for up to $48 \mathrm{~h}$ and the succession of community structure was observed. Bacterial abundances in the magnetically separated samples showed only a slight increase during up to $8 \mathrm{~h}$ of incubation, in parallel with those of total bacteria (the former accounted for about $6 \%$ of the latter) (Fig. 3). This was followed by a marked increase after 24 and $48 \mathrm{~h}$ of incubation. The community structure followed this tendency (Fig. 4). Those communities collected by particles were relatively stable for the first $8 \mathrm{~h}$ of incubation; a considerable change was then noticed at 24 or $48 \mathrm{~h}$, while the community structure of the $\mathrm{sF}$ control changed little. The results indicate that the change in the community structure of $130 \mathrm{nmDF}$ was relatively minor for the first $8 \mathrm{~h}$ of incubation by the magnetic separation method.

\section{Effect of particle size and composition}

We compared the bacterial community structures of samples separated by particles of different size and composition. Experiments were conducted on samples collected in October 2006 from Yokohama Port and Shinagawa Port in Tokyo Bay. Bacterial abundances, separated according to each type of particle (130nmDF, 150nmSF, 250nmDF, 300nmSF, 500nmDF, $500 \mathrm{nmSF}, 6 \mu \mathrm{mSF}, 6 \mu \mathrm{mPF}$; Table 1), ranged from $0.98 \times$ $10^{5}$ to $2.2 \times 10^{5}$ cells ml ${ }^{-1}$ or from 6 to $14 \%$ of $\mathrm{sF}(1.62 \times$
$10^{6}$ cells $\mathrm{ml}^{-1}$ ) for Yokohama Port samples, and from $0.69 \times 10^{5}$ to $1.6 \times 10^{5}$ cells ml $^{-1}$ or from 10 to $18 \%$ of $\mathrm{sF}$ $\left(4.8 \times 10^{5}\right.$ cells ml $\left.^{-1}\right)$ for the Shinagawa Port samples.

Analysis of the DGGE banding patterns of the samples collected by each type of paramagnetic particle (130nmDF, 150nmSF, 250nmDF, 300nmSF, 500nmDF, $500 \mathrm{nmSF}, 6 \mu \mathrm{mSF}, 6 \mu \mathrm{mPF}$ ) and of natural seawater samples $(\mathrm{sF})$ revealed that they shared few bands (Figs. 5A \& 6A). However, the magnetically separated samples shared some DGGE banding patterns and

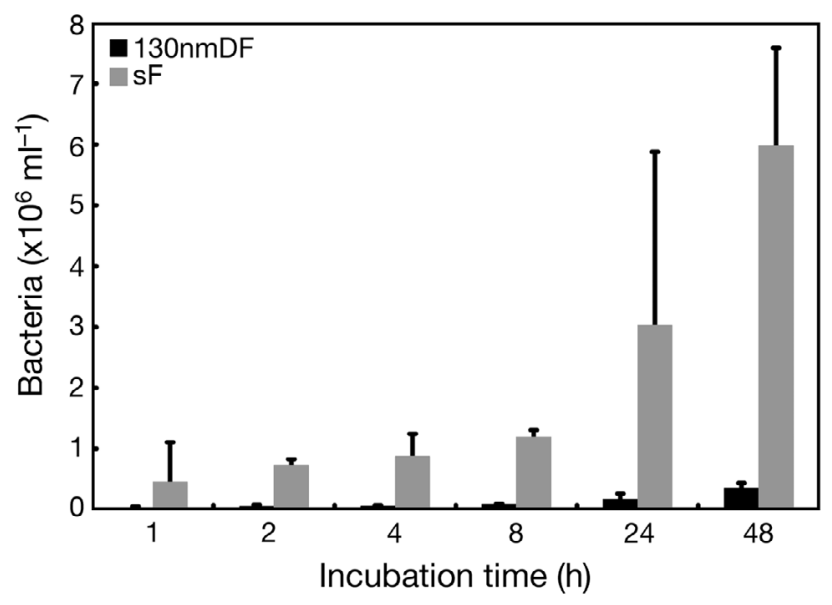

Fig. 3. Effect of incubation time with $130 \mathrm{~nm}$ diameter dextran particles on number of bacteria recovered by the magnetic separation method. See Fig. 2 for explanation of $\mathrm{sF}$ and 130nmDF. Error bars represent SD 


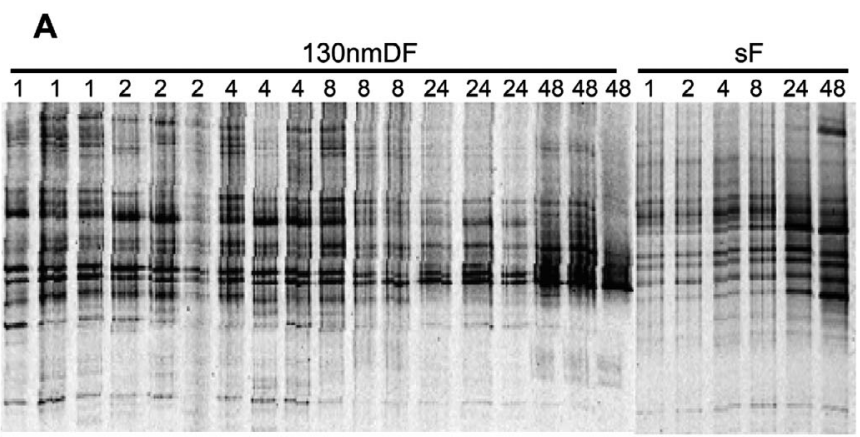

Fig. 4. (A) DGGE banding profiles and (B) MDS map for the succession of bacterial community structure during time course incubation with $130 \mathrm{~nm}$ diameter dextran particles. Numbers above the gel images in (A) and encircled in (B) correspond to the incubation time (h). See Fig. 2 for explanations of sF and 130nmDF

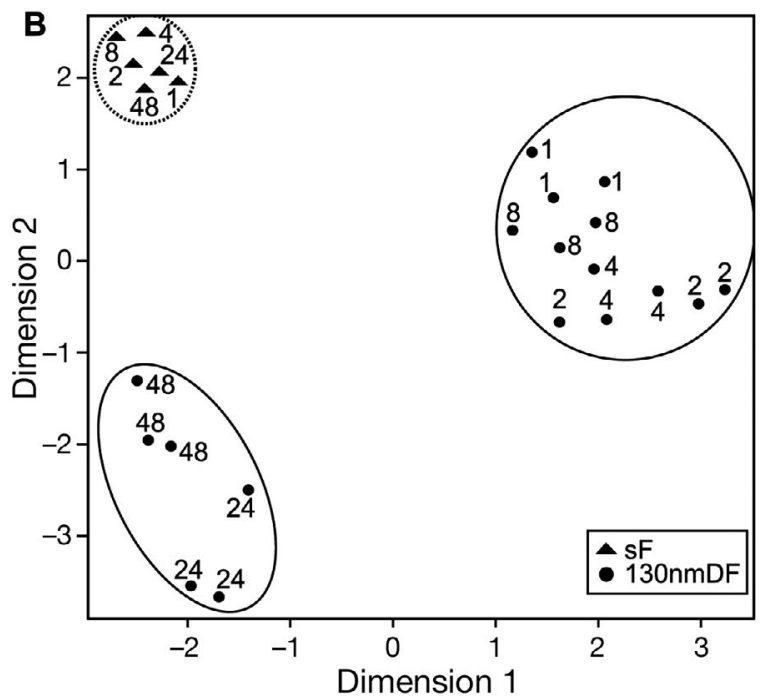

each duplicate sample showed a similar pattern. The banding patterns of $6 \mu \mathrm{mSF}$ and $6 \mu \mathrm{mPF}$ appeared quite different from those of the SMP samples, and the patterns were also slightly different between each duplicate. Samples collected using particles smaller than $500 \mathrm{~nm}(130 \mathrm{~nm}, 150 \mathrm{~nm}, 250 \mathrm{~nm}, 300 \mathrm{~nm})$ had many bands in common. Close inspection of these patterns revealed that several bands of $130 \mathrm{nmDF}$ and $250 \mathrm{nmDF}$ (dextran particles) were absent in 150nmSF and 300nmSF (silica particles), or they appeared only in $150 \mathrm{nmSF}$ and $300 \mathrm{nmSF}$. Most of the bands from the small particle samples (130nmDF, 150nmSF,
250nmDF, 300nmSF) also appeared in 500nmDF and $500 \mathrm{nmSF}$, but some appeared only very faintly in $500 \mathrm{nmDF}$ and 500nmSF. These results were consistent among Yokohama Port and Shinagawa Port samples.

The MDS map clearly showed the similarities and dissimilarities of these banding patterns (Figs. 5B \& 6B). Magnetically separated samples were plotted away from sF. Samples of SMPs $(130 \mathrm{~nm}, 150 \mathrm{~nm}$, $250 \mathrm{~nm}, 300 \mathrm{~nm})$ were plotted away from $6 \mu \mathrm{m}$ samples. Dextran (130nmDF, 250nmDF) and silica (150nmSF, 300nmSF) particle samples tended to clus-
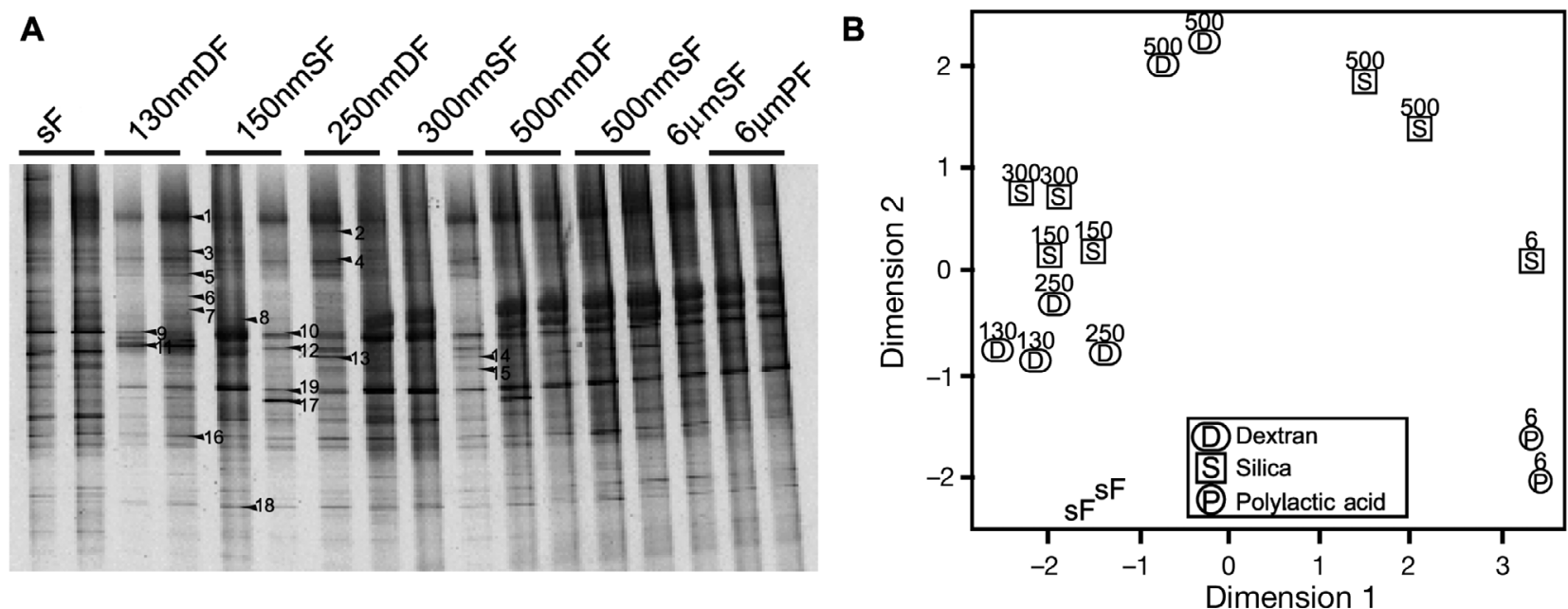

Fig. 5. (A) DGGE banding profiles and (B) MDS map of bacteria recovered from Yokohama Port samples by paramagnetic particles of different sizes and compositions. See Fig. 2 for explanation of sF. Magnetically separated samples were designated by particle size and composition as follows: 130nmDF (130 nm, dextran); 150nmSF (150 nm, silica); 250nmDF (250 nm, dextran); $300 \mathrm{nmSF}(300 \mathrm{~nm}$, silica); 500nmDF $(500 \mathrm{~nm}$, dextran); 500nmSF $(500 \mathrm{~nm}$, silica); $6 \mu \mathrm{mSF}(6 \mu \mathrm{m}$, silica); and $6 \mu \mathrm{mPF}(6 \mu \mathrm{m}$, polylactic acid) 

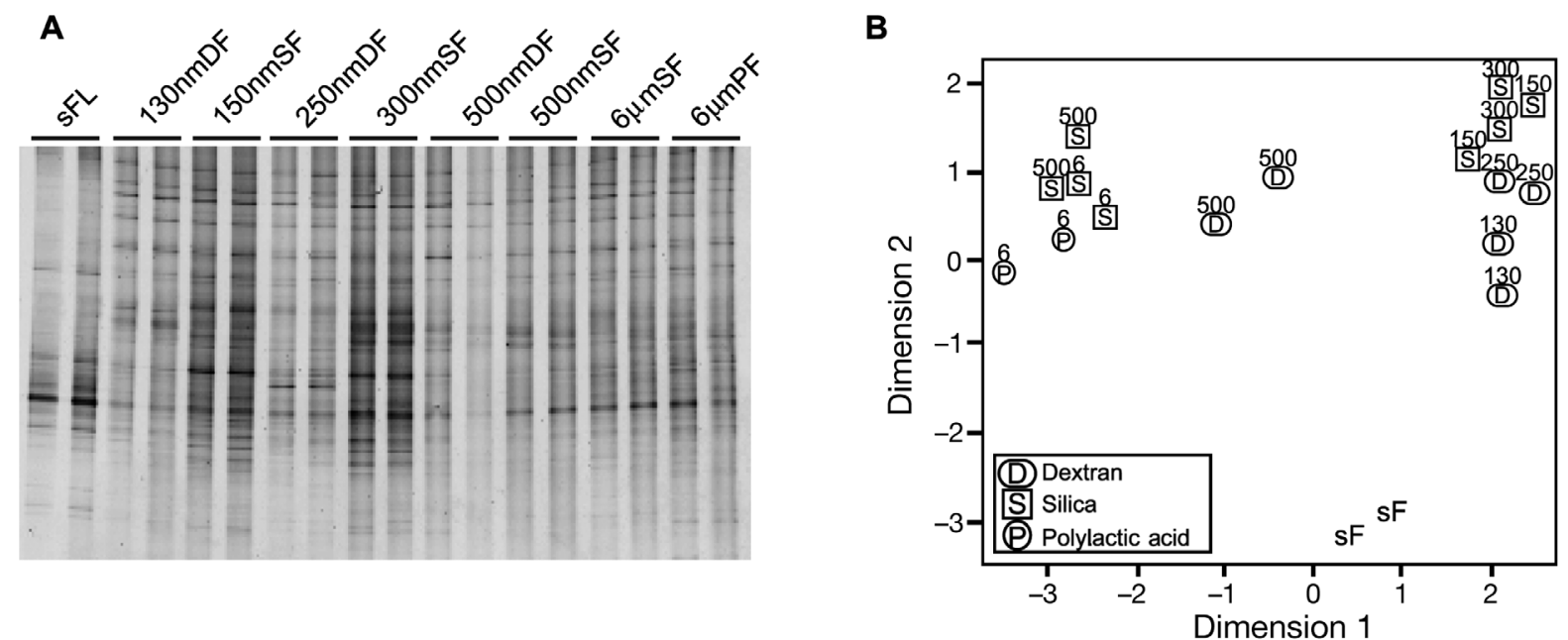

Fig. 6. (A) DGGE banding profiles and (B) MDS map of bacteria recovered from Shinagawa Port samples by paramagnetic particles of different sizes and compositions. See Fig. 5 for further explanations

ter together. Silica and polylactic acid samples of $6 \mu \mathrm{m}$ particles were plotted away from each other. These results were consistent for both Yokohama Port and Shinagawa Port samples. The community collected with $500 \mathrm{~nm}$ particles at Yokohama Port was located in the middle of those collected with larger and smaller particles (Fig. 5B), whereas those at Shinagawa Port were plotted close to $6 \mu \mathrm{mSF}$ and $6 \mu \mathrm{mPF}$ (Fig. 6B).

Nineteen DNA fragments contained in the DGGE bands were sequenced from magnetically separated samples from Yokohama Port (Fig. 5A). Phylotypes belonging to the Alpha-, Beta-, and Gammaproteobacteria, Actinobacteria, and CFB group (CytophagaFlavobacterium-Bacteroides) phyla were obtained (Table 2). Two Alphaproteobacteria phylotypes of SMP samples were closely related to Roseobacter isolates. Gammaproteobacteria phylotypes were closely related to Oceanobacter and Oceanospirillum isolates, especially Band 14, which showed 98\% similarity to Oceanobacter kriegii. The Actinobacteria phylotype was most closely related to a pathogenic isolate from a coastal environment.

Band 1, which belongs to the CFB group, appeared in all magnetically separated samples (Fig. 5A). Bands 11, 12, 14 and 16, which are Gammaproteobacteria, also occurred broadly among magnetically separated samples. Bands that appeared much darker in SMP (130nmDF, 150nmSF, 250nmDF, 300nmSF) were mostly related to Alpha- and Betaproteobacteria. The DNA contained in Band 17, which belongs to the Alphaproteobacteria, was sequenced from 130nmDF, 150nmSF, 250nmDF and 300nmSF. Also, Bands 8, 13 and 19, which are Betaproteobacteria, appeared prominent in $130 \mathrm{nmDF}, 150 \mathrm{nmSF}, 250 \mathrm{nmDF}$ and 300nmSF.

\section{Relative number of particle-possessing cells among natural samples}

Bacterial cells collected from samples from both coastal and open ocean environments and concentrated on Isopore filters were observed under AFM, and those surrounded by particulate materials were counted. The size and number of particles on each cell were variable and it was difficult to distinguish any general trends. Fig. 7 shows images of typical particlepossessing cells. The relative numbers of particle-possessing cells at each station are shown in Fig. 8. Numbers were high in the inner part of Tokyo Bay (Stns T1, T2), but few were detected in the surface layers at other stations. Among the offshore stations, the ratios were relatively high in the middle layer (500 to $2000 \mathrm{~m}$ ) and declined with depth.

The filters for the AFM observations were not washed after the filtration because it could have caused morphological changes in the bacterial cells. However, this left the possibility that salt crystals precipitated on the cell surfaces could have been mistaken for SMPs. To check for this possibility, samples from coastal environments and freshwater lakes (Fig. 1) were observed before and after being washed with $10 \mathrm{ml}$ distilled water (DW) (Table 3). The relative numbers of particle-possessing cells varied with the sampling station. The number decreased slightly after washing. These trends were consistent among marine and freshwater samples. The extent of the decrease was within the $95 \%$ confidence limit as calculated by chi-squared distribution. Finally, we used secondary ion mass spectrometry (Nano-SIMS 50/50L, Cameca), and SEM-EDX (scanning electron microscopy-energy dispersive X-ray spectroscopy, SUPERSCAN SSX-550, 
Table 2. DGGE band DNA sequences of phylotypes obtained from Yokohama Port. CFB: Cytophaga-FlavobacteriumBacteroides group

\begin{tabular}{|lclccc|}
\hline Category & Band no. & Nearest neighbor & Accession no. & \% similarity & Accession no. \\
\hline CFB & 1 & Unknown (PI_4q10f) & AY580698 & 99 & EF123234 \\
& 2 & Flavobacteriales (NorSea73) & AM279213 & 94 & EF123235 \\
& 3 & Unknown (PRE-S13) & DQ656247 & 96 & EF123236 \\
& 4 & Unknown (MSB-5B11) & DQ811911 & 95 & EF123237 \\
& 5 & Unknown (DGGE band B286) & DQ473568 & 92 & EF123238 \\
& 6 & Unknown (DGGE band BP15) & DQ656190 & 97 & EF123239 \\
Alphaproteobacteria & 7 & Unknown (ECS-P39) & DQ270285 & 96 & EF123240 \\
& 9 & Roseobacter (JL-ECS-X3) & AY663966 & 96 & EF123242 \\
Betaproteobacteria & 15 & Unknown (PENS_41) & AM238614 & 94 & EF123248 \\
& 17 & Rhodobacteraceae (SIMO-4309) & DQ421674 & 95 & EF123250 \\
& 8 & Burkholderia (B7) & AY752916 & 99 & EF123241 \\
Gammaproteobacteria & 10 & Unknown (SW20) & AY317112 & 90 & EF123243 \\
& 13 & Unknown (BAL58) & AB272375 & 98 & EF123246 \\
& 19 & Variovorax (1-O-1) & AM410900 & 99 & EF123244 \\
Actinobacteria & 12 & Oceanobacter (SIMO-2804) & AY70142298 & 94 & EF123245 \\
& 14 & Oceanospirillum kriegii & AB006767 & 98 & EF123247 \\
& 16 & Oceanospirillum (ESP60-Khe2-33) & DQ810516 & 99 & EF123249 \\
& 18 & Propionibacterium (215) & DQ189779 & 92 & EF123251 \\
\hline
\end{tabular}

Shimadzu) to directly identify the elements around the cells. Although trace amounts of sodium ions present around the cells were confirmed, no clear crystal precipitation was detected (data not shown).

\section{DISCUSSION}

In the present study, we hypothesized that some bacterial groups contact and retain SMPs on their cell surfaces by PC. To test this hypothesis we initially confirmed the presence of PC bacterial communities using

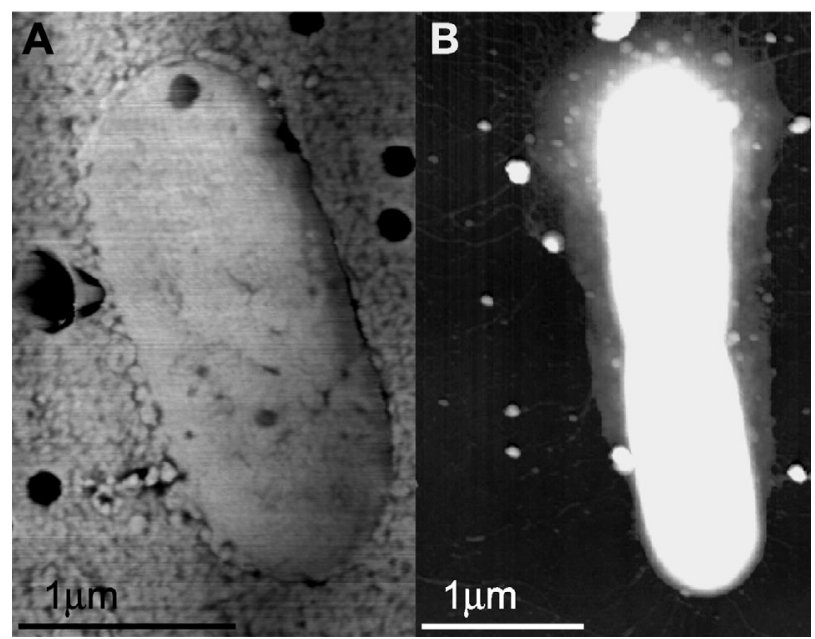

Fig. 7. Atomic force microscopy images of natural bacterial cells with submicron particles on their surfaces. (A) Nonfibrous cell and (B) fibrous cell paramagnetic particles. Second, we applied paramagnetic particles of various sizes and compositions to see whether the degree of PC depends on the size and/or composition of particles. Finally, we used AFM to observe SMPs on naturally occurring bacterial cells. Our results indicated that there are bacteria in the ocean that possess PC ability.

\section{Evaluation of the method}

As a first application to natural bacterial populations, we performed methodological examinations on coastal seawater using dextran paramagnetic particles with a nominal diameter of $130 \mathrm{~nm}$. Triplicate samples were prepared to check the reproducibility of the number of bacterial cells and the community structures recovered by this method. Our results showed that the abundances of magnetically separated bacterial cells were constant at approximately $10 \%$ of total bacteria throughout the investigations. MDS mapping showed that the community structures among the triplicate samples generally agreed well and that community structures of magnetically separated bacteria were different from those in natural seawater (Figs. 2B, 5B \& 6B). Because the number of particles added to the samples exceeded those of bacteria by 5 orders of magnitude, the bacteria-particle collision frequency was not a factor in this selection; instead, the unique interaction between the bacterial surface components and the particles should have been the critical factor. 


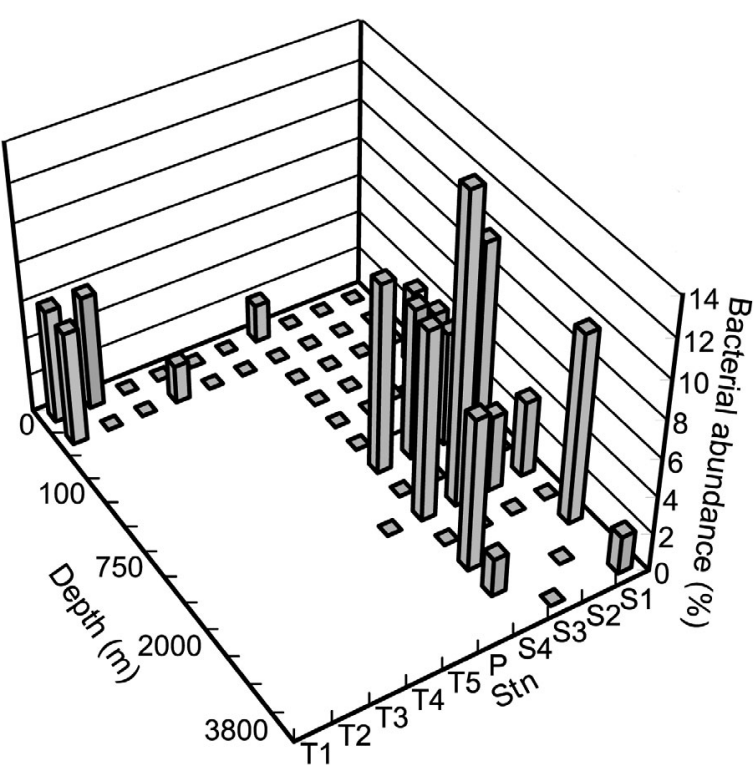

Fig. 8. Relative abundances of bacteria with submicron particles on their surfaces as detected by atomic force microscopy. Station locations where samples were obtained are described in Fig. 1

As a standard protocol, we chose a $1 \mathrm{~h}$ period for the incubation of seawater or bacterial cells with paramagnetic particles. This is because our preliminary investigation showed that the number of bacteria recovered by this method increased rapidly at the beginning, and then reached a plateau within $1 \mathrm{~h}$, followed by a slower increase (Figs. 3 \& 4). Kiørboe et al. (2002) also reported that bacteria colonized on model agar aggregates showed a saturation response within about 1 to $2 \mathrm{~h}$ in still water. A $1 \mathrm{~h}$ incubation period is practical for the treatment of many samples simultaneously in the field, and a longer incubation time could be expected to induce secondary processes owing to physiological changes and growth of the bacteria. The bacterial community structures changed slightly over the first $8 \mathrm{~h}$, with a concomitant slow increase in the

Table 3. Effects of $\mathrm{NaCl}$ on atomic force microscopy analysis. Sampling locations referred to in the table are given in Fig. 1

\begin{tabular}{|c|c|c|c|c|c|}
\hline \multirow{3}{*}{$\begin{array}{l}\text { Sampling } \\
\text { date } \\
(2006)\end{array}$} & \multirow{3}{*}{$\begin{array}{l}\text { Sampling } \\
\text { location }\end{array}$} & \multicolumn{4}{|c|}{ Number of cells } \\
\hline & & \multicolumn{2}{|c|}{ Before washing } & \multicolumn{2}{|c|}{ After washing } \\
\hline & & $\begin{array}{c}\text { With } \\
\text { particles }\end{array}$ & Total & $\begin{array}{c}\text { With } \\
\text { particles }\end{array}$ & Total \\
\hline 30 Aug & Yokohama & 37 & 150 & 18 & 150 \\
\hline $15 \mathrm{Sep}$ & Manazuru & 5 & 150 & 9 & 150 \\
\hline $1 \mathrm{Sep}$ & Misaki & 11 & 150 & 8 & 150 \\
\hline 12 Oct & Shinagawa & 21 & 150 & 18 & 150 \\
\hline $2 \mathrm{Nov}$ & Lake Kamakurako & 13 & 100 & 11 & 100 \\
\hline 17 Nov & Lake Ashinoko & 10 & 100 & 8 & 100 \\
\hline Total & & 97 & 800 & 72 & 800 \\
\hline
\end{tabular}

number of bacteria recovered, followed by a drastic shift after 1 or $2 \mathrm{~d}$ (Fig. 4). This change in structure may be due to the induction of PC ability and/or growth of certain bacteria that utilize the organic materials in the original seawater or the dextran contained in the model particles added.

In light of the reproducibility of our magnetic separation method, its ability to recover unique bacterial populations and the simplicity of the procedure, we concluded that this method is applicable to various aquatic environmental samples.

\section{Particle size and composition}

The methodology was first examined using dextran particles $130 \mathrm{~nm}$ in diameter, although we hypothesized that apparent PC ability could vary with particle size and chemical composition. When particles larger than bacterial cells were applied, we expected that the bacterial cells were attaching to the particles rather than capturing them. To test this hypothesis, we applied particles ranging from $130 \mathrm{~nm}$ to $6 \mu \mathrm{m}$. In addition, particles of different compositions were applied to examine whether this difference would lead to the recovery of different bacterial groups.

The community structures of bacteria separated using particles 130, 250 and $300 \mathrm{~nm}$ in diameter were different from those of bacteria separated using particles $500 \mathrm{~nm}$ and $6 \mu \mathrm{m}$ in diameter (Figs. 5 \& 6). In the case of the Shinagawa Port samples, the community structures of the bacteria separated using the $500 \mathrm{~nm}$ particles were close to those of the bacteria separated with the $6 \mu \mathrm{m}$ particles (Fig. 6B), whereas in the Yokohama Port samples, MDS mapping placed the structures of the communities separated with the $500 \mathrm{~nm}$ particles in between those on the larger and smaller particles (Fig. 5B). As the size of the $500 \mathrm{~nm}$ particles is comparable with that of most bacterial cells in natural seawater (Ducklow 2000), this result cannot be regarded as reflecting simply capture or attachment. These results indicate that the way bacterial cells interact with particles depends primarily on the particle size, and that PC cannot be regarded as the same as the attachment process.

To a lesser extent, the composition of the particles also affected the structures of the bacterial communities recovered (Figs. $5 \& 6$ ). We used particles made of commercially available dextran, silica or polylactic acid. For example, dextran is a mixture of flexible polymers of various molecular 
weights (4000 to 500000$)$ and is easily metabolized by various bacteria. Dextran has also been used to investigate bacterial attachment to dynamic fluid interfaces (Žutić et al. 1999). The MDS map showed that samples collected using particles made of the same matrix were plotted closely, whereas samples collected using particles made from different matrices tended to be plotted apart (Figs. 5B \& 6B). This result suggests that bacteria with PC ability may be able to recognize the quality of the particles and select preferentially the composition of the particles to be captured.

\section{Mechanisms of particle capture and attachment}

Both PC ability and attachment can be explained by the interaction of bacterial cell surface structure and the particles or surface. We considered that the chemical structure, length and number of fibrous materials on the cell probably play a central role in determining bacterial preferences in regard to the size and quality of particles (Morisaki et al. 1999). Bacteria have pili, structures that are used for attachment and are composed of sticky adhesins (Scott et al. 1996). Some types of pili or related fibrous structures may function to capture the SMPs. Fig. 7B indicates the presence of these fibrous materials. However, images taken by AFM did not always show such clear structures around the cells (Fig. 7A). This may be partly because of technical problems; as the cells have to be dried on a glass or filter surface before AFM observation, these fibrous materials may not be recognized easily. Another possible reason may be that such long and special structures may not be strictly necessary to capture fine particles.

For the observation of cells by AFM, bacterial cells were concentrated on the Isopore filter without washing, because washing could have caused deformation of the cells or surface components (Fig. 7). Therefore, we could not completely reject the possibility that the particles around the cells contained salt crystals. However, we consider this possibility to be small, for the following reasons. First, if there had been salt crystals, they should have appeared regardless of the sampling stations or depth. As shown in Fig. 8, this was not the case. Second, similar particles on the cells were noticed among freshwater samples after the same treatment (Table 3); the freshwater results were consistent with the results from samples found in the inner part of Tokyo Bay. Third, when the filters were washed with DW, the relative numbers of particle-possessing cells only decreased slightly for both freshwater and marine samples (Table 3).

These results raise many questions: How do cells recognize the size of particles? How do cells recognize the quality of particles? What determines the preferences for such characteristics? What kinds of forces act in the capture? And how quickly are particles captured and metabolized? These questions have never been raised before and are all involved in very basic bacterial functions. To answer these questions, we need to accumulate experimental data under defined conditions and from defined observations of cell surface structure using either electron microscopy or AFM. Visual observation may, however, be hindered by potential artifacts from sample preparation.

\section{Ecological implications}

In the ocean the numbers of SMPs exceed those of bacterial cells by 1 or 2 orders of magnitude (Koike et al. 1990, Longhurst et al. 1992, Wells \& Goldberg 1994). As these particles are mostly of biological origin (Koike et al. 1990, Shibata et al. 1999), they may serve as organic substrates for bacterial cells. Bacterial cells depend on extracellular enzymes to degrade these particles, but the enzymes would be expected to diffuse away once they are excreted. If cells possess PC ability, however, they should be able to utilize SMPs with minimum loss of enzymes and degraded materials. Particle capture may also help the cells to recognize the chemical nature of SMPs and to synthesize appropriate enzymes. These advantages can be expected among bacterial cells with PC ability in any aquatic environment.

Fig. 8 indicates that the number of bacteria with SMPs on their surfaces was high in the inner part of Tokyo Bay. This may be due to the inflow of large numbers of particles as pollutants in the area. On the other hand, the broad peaks in the mid-pelagic layers in the open ocean area can be interpreted in relation to the vertical flux of marine snow or particulate organic matter in the ocean (Azam \& Long 2001). As marine snow sinks, the components are gradually dissolved or converted to the dissolved organic matter fraction by the hydrolyzing activity of attached bacteria (Cho \& Azam 1988). Kiørboe \& Jackson (2001) made a model of sinking marine snow that left organic solute plumes. Dissolved organic carbon (DOC) thus supported the growth of free-living bacteria present in the water column (Alldredge \& Gotschalk 1990, Smith et al. 1992). It seems reasonable to assume that this DOC fraction contains colloidal particles that are captured and utilized by free-living bacterial cells. In the midpelagic layers, the low bacterial metabolic activity due to low temperature, low nutrient concentrations and high pressure may increase the retention time of particles on the cell surface.

In conclusion, we developed a new method of separating PC bacterial groups and confirmed their pres- 
ence in marine environments, and we also observed the bacterial cells possessing the PC ability in natural environments. To our knowledge, this is the first conceptual model of how bacteria utilize colloidal particles or high molecular weight organic materials. This concept should have fundamental importance in considerations of the basic mechanisms of bacterial metabolism and functions in the ocean.

\section{LITERATURE CITED}

Alldredge AL, Gotschalk CC (1990) The relative contribution of marine snow of different origins to biological processes in coastal waters. Cont Shelf Res 10:41-58

Altschul SF, Gish W, Miller W, Myers EW, Lipman DJ (1990) Basic local alignment search tool. J Mol Biol 215:403-410

Amon RM, Benner R (1994) Rapid cycling of high-molecularweight dissolved organic matter in the ocean. Nature 369: 549-552

Azam F, Long RA (2001) Sea snow microcosms. Nature 414: 495-498

Brzeska M, Panhorst M, Kamp PB, Schotter J, Reiss G, Puhler A, Becker A, Bruckl H (2004) Detection and manipulation of biomolecules by magnetic carriers. J Biotechnol 112:25-33

Cho BC, Azam F (1988) Major role of bacteria in biogeochemical fluxes in the ocean's interior. Nature 332:441-443

Chou Q, Russell M, Birch DE, Raymond J, Bloch W (1992) Prevention of pre-PCR mis-priming and primer dimerization improves low-copy-number amplifications. Nucleic Acids Res 20:1717-1723

Don RH, Cox PT, Wainwright BJ, Baker K, Mattick JS (1991) 'Touchdown' PCR to circumvent spurious priming during gene amplification. Nucleic Acids Res 19:4008

Ducklow H (2000) Bacterial production and biomass in the oceans. In: Kirchman D (ed) Microbial ecology of the oceans. Wiley-Liss, Toronto, p 85-120

Jackson GA, Burd A (2002) A model for the distribution of particle flux in the mid-water column controlled by subsurface biotic interactions. Deep-Sea Res II 49:193-217

Kanagawa T (2003) Bias and artifacts in multitemplate polymerase chain reactions (PCR). J Biosci Bioeng 96:317-323

Kiørboe T, Jackson GA (2001) Marine snow, organic solute plumes, and optimal chemosensory behavior of bacteria. Limnol Oceanogr 46(6):1309-1318

Kiørboe T, Grossart H, Ploug H, Tang K (2002) Mechanisms and rates of bacterial colonization of sinking aggregates. Appl Environ Microbiol 68(8):3996-4006

Koike I, Hara S, Terauchi K, Kogure K (1990) Role of submicrometre particles in the ocean. Nature 345:242-243

Longhurst AR, Koike I, Li WKW, Rodriguez J and others (1992) Sub-micron particles in northwest Atlantic shelf water. Deep-Sea Res 39:1-7

Morisaki H, Nagai S, Ohshma H, Ikemoto E, Kogure K (1999) The effect of motility and cell-surface polymers on bacterial attachment. Microbiology 145:2797-2802

Editorial responsibility: Fereidoun Rassoulzadegan, Villefranche-sur-Mer, France
Muyzer G, de Waal EC, Uitterlinden AG (1993) Profiling of complex microbial populations by denaturing gradient gel electrophoresis analysis of polymerase chain reactionamplified genes coding for 16S rRNA. Appl Environ Microbiol 59:695-700

Muyzer G, Brinkoff T, Nubel U, Santegoeds C, Schafer H, Wawer C (1998) Denaturing gradient gel electrophoresis (DGGE) in microbial ecology. In: Akermans ADL, van Elsas JD, de Brujin FJ (eds) Molecular microbial ecology manual. Kluwer Academic Publishers, Dordrecht, p 1-27

Nishino T, Ikemoto E, Kogure K (2004) Application of atomic force microscopy to observation of marine bacteria. J Oceanogr 60:219-225

O'Dowd CD, Facchini MC, Cavalli F, Ceburnis D and others (2004) Biogenetically driven organic contribution to marine aerosol. Nature 431:676-680

Porter KG, Feig YS (1980) The use of DAPI for identifying and counting aquatic microflora. Limnol Oceanogr 25(5): 943-948

Pyle BH, Broadaway SC, McFeters GA (1999) Sensitive detection of Escherichia coli O157:H7 in food and water by immunomagnetic separation and solid-phase laser cytometry. Appl Environ Microbiol 65:1966-1972

Scott JH, Jones CH, Normark S (1996) Bacterial adhesins and their assembly. In: Frederick CN, Curtiss R III, Ingraham JL, Lin ECC and others (eds) Escherichia coli and Salmonella, Vol 2. ASM Press, Washington, DC, p 2730-2756

Shibata A, Kogure K, Koike I, Ohwada I (1999) Formation of submicron colloidal particles from marine bacteria by viral infection. Mar Ecol Prog Ser 155:303-307

Sieracki ME, Viles CL (1992) Distributions and fluorochrome staining properties of submicrometer particles and bacteria in the North Atlantic. Deep-Sea Res 39:1919-1929

Smith DC, Silver MW, Alldredge AL, Azam F (1992) Intense hydrolytic activity on marine aggregates and implications for rapid particle dissolution. Nature 359:139-141

Thompson JD, Higgins DG, Gibson TJ (1994) CLUSTAL W: improving the sensitivity of progressive multiple sequence alignment through sequence weighting, position-specific gap penalties and weight matrix choice. Nucleic Acids Res 22:4673-4680

Van Hannen EJ, Veninga M, Bloem J, Gons HJ, Laanbroek HJ (1999) Genetic changes in the bacterial community structure associated with protistan grazers. Arch Hydrobiol 145:25-38

Wells ML, Goldberg ED (1994) The distribution of colloids in the North Atlantic and Southern Ocean. Limnol Oceanogr 39:286-302

Yamasaki A, Fukuda R, Miyajima T, Nagata T, Ogawa H, Koike I (1998) Submicrometer particles in northwest Pacific coastal environments: abundance, size distribution, and biological origins. Limnol Oceanogr 43:536-542

Yoshida A, Nomura H, Toyoda K, Nishino T and others (2006) Microbial responses using denaturing gradient gel electrophoresis to oil and chemical dispersant in enclosed ecosystems. Mar Pollut Bull 52:89-95

Žutić V, Ivošević N, Svetličić V, Long RA, Azam F (1999) Film formation by marine bacteria at a model fluid interface. Aquat Microb Ecol 17:231-238

Submitted: May 2, 2006; Accepted: September 11, 2007

Proofs received from author(s): November 1, 2007 